\title{
Political regime change, economic liberalization and growth accelerations
}

\author{
Richard Jong-A-Pin · Jakob De Haan
}

Received: 17 April 2009 / Accepted: 14 December 2009 / Published online: 13 January 2010

(C) The Author(s) 2010. This article is published with open access at Springerlink.com

\begin{abstract}
We examine whether the type of political regime, regime changes, and economic liberalization are related to economic growth accelerations. Our results show that growth accelerations are preceded by economic liberalizations. We also find that growth accelerations are less likely to happen the longer a political regime-be it a democracy or an autocracyhas been in place, while (a move toward) more democracy according to the Polity IV dataset reduces the likelihood of growth accelerations.
\end{abstract}

Keywords Economic growth accelerations · Political regime $\cdot$ Regime changes · Economic liberalization

JEL Classification $\mathrm{O} 17 \cdot \mathrm{O} 11$

\section{Introduction}

Various studies have examined whether economic liberalization and the political regime in place affect a country's economic growth performance. ${ }^{1}$ However, evidence based on cross-

\footnotetext{
${ }^{1}$ For a survey of the relationship between economic growth and political regimes, see, e.g., Przeworski et al. (2000). Winters (2004) provides an overview of the relationship between trade liberalization and economic growth, while the literature on economic liberalization and economic growth is surveyed by De Haan et al. (2006). A somewhat related contribution is Crain (2003).
}

R. Jong-A-Pin · J. De Haan ( $\varangle)$

Faculty of Economics and Business, University of Groningen, PO Box 800, 9700 AV Groningen,

The Netherlands

e-mail: Jakob.de.Haan@rug.nl

R. Jong-A-Pin

ETH, Zürich, Switzerland

J. De Haan

CESifo, Munich, Germany

J. De Haan

The Netherlands Bank, Amsterdam, The Netherlands 
country growth regressions has been criticized for its limited ability to address causality (Durlauf et al. 2005). Furthermore, cross-country growth regressions rely on very strong assumptions about a single linear model being appropriate for all countries in all economic conditions, while only few countries had constant growth rates over periods of several decades (Pritchett 2000). ${ }^{2}$

Due to its fixation on long-run differences in growth, empirical research has underestimated the importance of instability and volatility in growth rates, especially in developing countries (De Haan 2007). The study by Pritchett (2000) was one of the first to identify that instability in growth rates over time for a single country is great, relative to both the average level of growth and the variance across countries. Jones and Olken (2008) report that no less than 48 countries have experienced one or more structural breaks in their economic development. These breaks led to very distinct growth patterns. Whereas some countries had long periods of sustained growth, others faced rapid growth followed by stagnation or even a period of crisis. Still, other countries faced continuous stagnation or steady decline.

One promising research strategy attempts using this diversity in growth patterns to examine whether economic, political, institutional, and policy conditions affect economic development. Although still small, this line of research focusing on the time dimension of economic growth is burgeoning rapidly. A good example is the study by Jones and Olken (2005), who examine whether the death of national leaders due either to accident or natural cause leads to a different growth rate. They find evidence that change of leadership matters, notably so in autocratic regimes. Probably the best-known study of growth accelerations is by Hausmann et al. (2005), who conclude that growth accelerations are often preceded by political regime changes, while economic liberalization is hardly related to these accelerations.

Following up on the research by Hausmann et al. (2005), we propose a new way to identify so-called growth accelerations. Using data for 106 countries over the period 19571993, we identify 89 of these growth accelerations and examine whether they are related to the political regime in place, regime changes, or economic liberalization. Our results show that economic growth accelerations are preceded by economic liberalization and not by political regime changes. We also find that growth accelerations are less likely to happen the longer a political regime-be it a democracy or an autocracy - has been in place, while (a move toward) more democracy according to the Polity IV dataset reduces the likelihood of growth accelerations.

The paper proceeds as follows. Section 2 offers a brief discussion of previous studies, outlining what may drive growth accelerations. Section 3 discusses our filter to identify economic growth accelerations. Section 4 analyzes the relationship between political regime changes, economic liberalization, and growth accelerations, while Sect. 5 examines the robustness of our results. Section 6 concludes.

\section{What drives growth accelerations?}

Hausmann et al. (2005) look for growth accelerations during 1957-1992 and report many such episodes even in countries that have under-performed during this period in terms of average growth. These authors argue that growth accelerations can be triggered by favorable

\footnotetext{
${ }^{2}$ Various authors have therefore used panel models, but the periods chosen in panel models are often justified only on the grounds that data were available at those frequencies or the researcher wanted to divide the whole period into equal chunks (Pritchett 2000).
} 
external conditions and changes in the underlying political balance as revealed by transformations in the political regime. Likewise, economic liberalization may be conducive to growth accelerations. Indeed, there is substantial evidence that economic liberalization stimulates long-term growth (Giavazzi and Tabellini 2005), so it is also likely that growth accelerations may be affected by economic liberalization. Hausmann et al. (2005) find that growth accelerations are often preceded by political regime changes, while economic liberalization is hardly related to these accelerations. ${ }^{3}$ Imam and Salinas (2008) report for a group of 22 Western African economies for the period 1960-2006 that growth accelerations are most clearly associated with external shocks, economic liberalization, political stability, and closeness to the coast. Timmer and De Vries (2009) find that growth accelerations are explained by productivity increases within sectors, but not by reallocation of employment to more productive sectors. They base their findings on the Groningen Growth and Development Center (GGDC) database, which consists of annual time series of value added and persons employed for the ten main sectors of the economy and includes 19 countries in Asia and Latin America in the period from 1950 to 2005.

Here, we focus once more on the aggregate economy. We will not only examine whether political regime changes and economic liberalization affect the likelihood of growth accelerations, but also investigate whether the political regime matters. There is an extensive literature on the effect of democracy on economic growth (see, for instance, Tavares and Wacziarg 2001) based on cross-country or panel methods, but authors often come to different conclusions. One reason could be that democracy may have both positive and negative implications for growth. On the positive side, transparency and accountability may enhance economic performance. On the negative side, the consensus required by democratic institutions may delay responses to shocks and implementation of legislation. Doucouliagos and Ulubasoglu (2008) conclude on the basis of a meta-analysis that there is no clear evidence of democracy being detrimental to economic growth. The accumulated evidence points to a zero direct effect on economic growth.

Some recent studies focus on the time-series dimension of growth and examine whether growth accelerations are related to the political system in place. Jerzmanowski (2006) reports that democracy lowers the propensity for crises but also limits the frequency of episodes of very rapid growth, while Cuberes and Jerzmanowski (2008) report that democracy is the most robust predictor of a country's propensity for growth reversals.

However Clague et al. (1996) argue that it is not (the lack of) democratic rights that affect economic growth but the length of time that a particular regime has been in place, no matter whether the regime is democratic or autocratic. An autocrat expecting to rule for a long time would gain from respecting the property rights of individuals, in contrast to an autocrat with a short-term horizon, who will gain from expropriating the wealth of his subjects. Also, transitory democracies can easily suffer from expropriations that have the same harmful effects as the predations of an autocrat. In a lasting democracy, however, the situation "is utterly different not only from transitory democracies but also from autocratic governments. Though lasting democracies suffer from sclerotic accumulations of special-interest lobbying and (like all other types of governments) often have economically inefficient policies, they necessarily hold elections under law and the governmental leaders or parties that

\footnotetext{
${ }^{3}$ However, Jong-A-Pin and De Haan (2008) show that these conclusions are wrong as Hausmann et al. were led astray by a data-description error in the Polity IV manual. When they correct for the error, Jong-A-Pin and De Haan find that political regime changes are not related to the probability that growth accelerations occur.
} 
are defeated surrender power in accord with the law. There cannot be genuine elections unless even the leading opponents of the party in power have not only political rights but also the economic rights needed to obtain a livelihood." (Clague et al. 1996: 245). In an earlier work, Olsen (1982) stressed that a government that is in power for a long time will form a distributional coalition that will have incentives to influence policies in its favor. Since the benefits of these policies are concentrated among the coalition members while the costs are diffused throughout the whole population, they will face little public resistance. Over time, distributional coalitions accumulate and the nation burdened by them will fall into economic decline (Imam and Salinas 2008).

The importance of regime duration for economic growth is also stressed by studies on the relation between political instability and economic growth. Jong-A-Pin (2009) shows that countries with a stable political regime grow on average faster than countries without a stable political regime. On the other hand, Jong-A-Pin and Yu (2010) find that within politically unstable countries a leadership change accelerates economic growth-especially in the poorest counties. Hence, also from this point of view, the direction of the relation between regime duration and growth accelerations is not clear a priori. In our empirical analysis, we will also test whether the duration of a regime affects the likelihood that growth accelerations occur.

\section{Identifying growth accelerations}

To identify growth accelerations, we propose a simple criterion that first identifies all possible take-offs of growth accelerations. This criterion is similar to the so-called BBQ rule used to identify turning points in business cycles (Harding and Pagan 2002). To qualify as the potential start of any growth acceleration in year $t$, economic growth $(g)$ in the first year of the acceleration should be higher than in the year before: ${ }^{4}$

$$
g_{t+1}>g_{t} .
$$

If year $t$ satisfies this criterion, we check whether it also fulfills the three criteria proposed by Hausmann et al. (2005):

$$
\begin{aligned}
& g_{t, n+7}>3.5 \mathrm{ppa}, \\
& g_{t, n+7}-g_{t-7, t}>2.0 \mathrm{ppa} \\
& y_{t+7}>\max \left\{y_{i}\right\}, \quad i \leq t,
\end{aligned}
$$

where ppa is percent per annum. That is, to qualify as growth acceleration, the growth rate over an 8-year period must be at least $3.5 \%$ per annum. Furthermore, it must be at least two percentage points higher than in the previous 8 years. Finally, to rule out episodes of full economic recovery, the level of real GDP $(y)$ must be higher at the end of the acceleration than in all years before the acceleration. If these criteria are satisfied as well and year $t-1$ and year $t+1$ do not qualify, we identify year $t$ as the start of the growth acceleration. If consecutive years fulfill all criteria, we take the year in which the level of real GDP is minimal to be the starting point of the growth acceleration.

\footnotetext{
${ }^{4}$ In our robustness analysis, we also examine the criterion that the 2-year growth rate should exceed the 2year growth rate before the start of the growth acceleration. This alternative criterion ensures that economic growth not only accelerates, but also that the growth rate at the start of the acceleration is substantial.
} 
Fig. 1 Growth accelerations in Chile

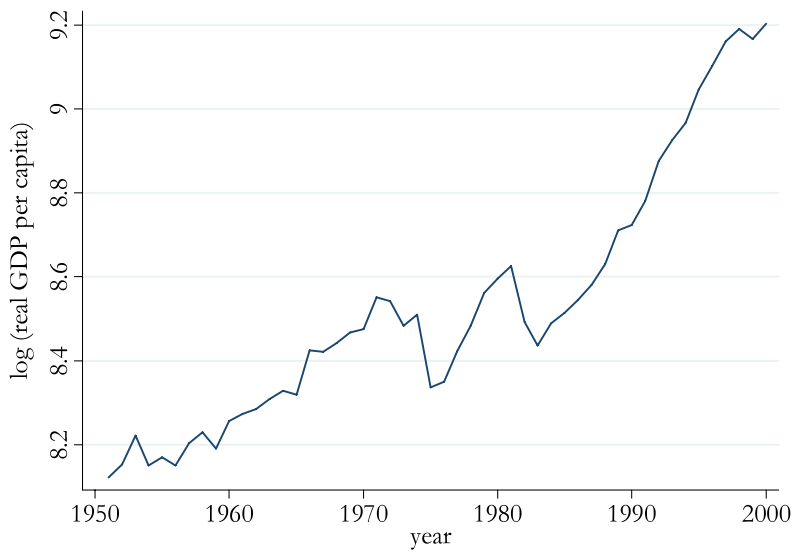

To exemplify our approach as well as the difference with the filter of Hausmann et al. (2005), consider the development of income per capita in Chile as illustrated in Fig. 1. The figure shows that after a long period of modest economic growth, there has been a rapid acceleration in economic growth at the beginning of the 1980s. According to our filter, 1983 qualifies as the start of the acceleration. In that year, economic growth was higher than in the year before ( $5 \%$ versus $-5 \%$ ), the average growth rate per annum over the 8 -year period was $4.2 \%$ per annum, and the difference between the 8 -year growth rate after the start of the acceleration and the 8 -year period before the acceleration is 2.5 percentage points. The figure also shows that the level of GDP per capita at the end of the acceleration exceeded the level at the start of the acceleration. As there is no earlier year that also meets all conditions, 1983 is taken as the start of the growth acceleration. Our filter identifies perfectly the trough after which economic growth takes of. In contrast, the filter of Hausmann et al. (2005) identifies 1986 as the start of the growth acceleration, i.e., the year in which their filter detects a structural break in the time series. Whereas both filters may seem reasonable, the filter of Hausmann et al. (2005) exhibits some counterintuitive features. For instance, according to their filter, 27 growth accelerations have a higher economic growth rate in the year before the acceleration than at the start of the acceleration. In the Appendix, we discuss this issue further. Since we are interested in the determinants that cause the start of a growth acceleration, we argue that our filter is more appropriate for our empirical analysis than the filter of Hausmann et al. (2005).

Using Penn World Table Data (Heston et al. 2002), our filter identifies 89 accelerations, which are reported in Table 1 . We checked how sensitive our findings are with respect to these criteria and it turned out that the accelerations that we identify are not very sensitive to reasonable changes in these criteria. ${ }^{5}$

As Table 1 shows, accelerations occur quite frequently in Africa, a continent normally not associated with high rates of economic growth. Figure 2 shows the average number of growth accelerations per year for the entire sample period. It can be seen that there is a decreasing trend over time. Nowadays, the likelihood of observing accelerations in economic growth is lower than in the period before 1970.

\footnotetext{
${ }^{5}$ More specifically, we tightened and relaxed our threshold values between 3-4\% per annum for the first restriction and between 1.5-2.5\% per annum for the second restriction. In the robustness analysis in Sect. 5, we show estimation results when these alternative restrictions are used.
} 
Table 1 Growth accelerations according to our filter

\begin{tabular}{|c|c|c|c|c|c|}
\hline Country & Year & $\begin{array}{l}\text { Growth } \\
\text { before } \\
\text { acceleration }\end{array}$ & $\begin{array}{l}\text { Growth } \\
\text { during } \\
\text { acceleration }\end{array}$ & $\begin{array}{l}\text { Difference } \\
\text { in growth } \\
\text { rate }\end{array}$ & $\begin{array}{l}\text { Post crisis } \\
\text { acceleration }\end{array}$ \\
\hline Algeria & 1975 & 2.14 & 4.20 & 2.06 & 0 \\
\hline Argentina & 1963 & 0.90 & 3.60 & 2.70 & 0 \\
\hline Argentina & 1990 & -3.10 & 6.10 & 9.20 & 1 \\
\hline Australia & 1961 & 1.55 & 3.80 & 2.25 & 0 \\
\hline Belgium & 1958 & 2.37 & 4.70 & 2.33 & 0 \\
\hline Botswana & 1970 & 3.33 & 11.40 & 8.07 & 0 \\
\hline Brazil & 1966 & 3.12 & 7.20 & 4.08 & 0 \\
\hline Cameroon & 1972 & -0.58 & 5.30 & 5.88 & 0 \\
\hline Canada & 1961 & 0.97 & 3.80 & 2.83 & 0 \\
\hline Chad & 1974 & -1.48 & 7.30 & 8.78 & 1 \\
\hline Chile & 1983 & 1.69 & 4.20 & 2.51 & 1 \\
\hline Chile & 1988 & 0.98 & 5.80 & 4.82 & 0 \\
\hline China & 1976 & 1.95 & 5.30 & 3.35 & 0 \\
\hline China & 1981 & 3.54 & 6.50 & 2.96 & 0 \\
\hline China & 1989 & 5.19 & 8.70 & 3.51 & 0 \\
\hline Colombia & 1967 & 1.56 & 4.00 & 2.44 & 0 \\
\hline Congo, Republic of & 1969 & 0.91 & 5.40 & 4.49 & 0 \\
\hline Congo, Republic of & 1977 & 3.75 & 8.70 & 4.95 & 0 \\
\hline Denmark & 1958 & 2.24 & 5.20 & 2.96 & 0 \\
\hline Dominican Republic & 1968 & -0.17 & 6.50 & 6.67 & 0 \\
\hline Dominican Republic & 1991 & 0.43 & 5.80 & 5.37 & 0 \\
\hline Ecuador & 1966 & 1.28 & 4.60 & 3.32 & 0 \\
\hline Ecuador & 1971 & 1.63 & 7.70 & 6.07 & 0 \\
\hline Egypt & 1975 & -1.14 & 5.50 & 6.64 & 1 \\
\hline Finland & 1958 & 2.72 & 5.00 & 2.28 & 0 \\
\hline Finland & 1968 & 2.84 & 5.30 & 2.46 & 0 \\
\hline Finland & 1993 & -0.41 & 4.40 & 4.81 & 0 \\
\hline Ghana & 1963 & -0.21 & 3.80 & 4.01 & 0 \\
\hline Guinea-Bissau & 1971 & -5.46 & 10.00 & 15.46 & 1 \\
\hline Guinea-Bissau & 1989 & -0.04 & 5.70 & 5.74 & 0 \\
\hline Haiti & 1989 & -2.29 & 9.30 & 11.59 & 0 \\
\hline India & 1982 & 1.47 & 3.90 & 2.43 & 0 \\
\hline Indonesia & 1967 & -0.76 & 5.50 & 6.26 & 0 \\
\hline Indonesia & 1987 & 3.41 & 5.50 & 2.09 & 0 \\
\hline Iran & 1991 & -1.53 & 4.60 & 6.13 & 0 \\
\hline Ireland & 1958 & 1.04 & 3.70 & 2.66 & 0 \\
\hline Ireland & 1986 & 1.45 & 4.90 & 3.45 & 0 \\
\hline Ireland & 1993 & 4.95 & 8.20 & 3.25 & 0 \\
\hline Israel & 1958 & 2.43 & 5.40 & 2.97 & 0 \\
\hline Israel & 1967 & 2.78 & 7.20 & 4.42 & 1 \\
\hline Japan & 1958 & 5.77 & 9.00 & 3.23 & 0 \\
\hline Jordan & 1971 & -3.13 & 6.00 & 9.13 & 1 \\
\hline
\end{tabular}


Table 1 (Continued)

\begin{tabular}{|c|c|c|c|c|c|}
\hline Country & Year & $\begin{array}{l}\text { Growth } \\
\text { before } \\
\text { acceleration }\end{array}$ & $\begin{array}{l}\text { Growth } \\
\text { during } \\
\text { acceleration }\end{array}$ & $\begin{array}{l}\text { Difference } \\
\text { in growth } \\
\text { rate }\end{array}$ & $\begin{array}{l}\text { Post crisis } \\
\text { acceleration }\end{array}$ \\
\hline Kenya & 1968 & 2.57 & 4.60 & 2.03 & 0 \\
\hline Korea, Republic of & 1960 & 1.93 & 4.90 & 2.97 & 0 \\
\hline Korea, Republic of & 1967 & 4.94 & 7.10 & 2.16 & 0 \\
\hline Korea, Republic of & 1981 & 5.50 & 7.80 & 2.30 & 0 \\
\hline Lesotho & 1969 & 1.72 & 3.90 & 2.18 & 0 \\
\hline Malawi & 1970 & 1.45 & 3.90 & 2.45 & 0 \\
\hline Malawi & 1992 & -0.79 & 4.80 & 5.59 & 0 \\
\hline Malaysia & 1971 & 2.96 & 5.00 & 2.04 & 0 \\
\hline Malaysia & 1986 & 2.28 & 5.50 & 3.22 & 0 \\
\hline Mali & 1993 & 0.16 & 3.70 & 3.54 & 0 \\
\hline Mauritius & 1969 & -1.49 & 4.70 & 6.19 & 0 \\
\hline Mauritius & 1983 & 1.01 & 5.50 & 4.49 & 0 \\
\hline Morocco & 1960 & -0.92 & 5.50 & 6.42 & 0 \\
\hline Nicaragua & 1959 & 1.14 & 5.20 & 4.06 & 0 \\
\hline Nigeria & 1967 & -1.72 & 7.30 & 9.02 & 1 \\
\hline Norway & 1991 & 1.42 & 3.60 & 2.18 & 0 \\
\hline Pakistan & 1960 & -1.76 & 4.30 & 6.06 & 1 \\
\hline Pakistan & 1977 & 1.64 & 4.40 & 2.76 & 0 \\
\hline Panama & 1959 & 1.46 & 5.40 & 3.94 & 0 \\
\hline Panama & 1976 & 1.93 & 5.30 & 3.37 & 0 \\
\hline Paraguay & 1973 & 2.65 & 5.90 & 3.25 & 0 \\
\hline Peru & 1959 & 0.85 & 5.20 & 4.35 & 1 \\
\hline Peru & 1990 & -2.18 & 4.00 & 6.18 & 1 \\
\hline Poland & 1991 & 0.50 & 4.80 & 4.30 & 1 \\
\hline Portugal & 1984 & 1.58 & 5.60 & 4.02 & 0 \\
\hline Romania & 1980 & 0.65 & 14.50 & 13.85 & 1 \\
\hline Rwanda & 1975 & 0.73 & 4.00 & 3.27 & 0 \\
\hline Singapore & 1967 & 7.00 & 10.60 & 3.60 & 0 \\
\hline Spain & 1959 & 4.45 & 8.00 & 3.55 & 0 \\
\hline Spain & 1984 & 0.11 & 3.80 & 3.69 & 0 \\
\hline Sri Lanka & 1979 & 1.86 & 4.10 & 2.24 & 0 \\
\hline Syria & 1968 & 1.40 & 4.30 & 2.90 & 0 \\
\hline Syria & 1974 & 2.63 & 4.80 & 2.17 & 0 \\
\hline Syria & 1989 & -2.89 & 4.40 & 7.29 & 0 \\
\hline Taiwan & 1960 & 3.32 & 6.80 & 3.48 & 0 \\
\hline Taiwan & 1966 & 6.12 & 8.60 & 2.48 & 0 \\
\hline Thailand & 1958 & -0.88 & 5.40 & 6.28 & 0 \\
\hline Thailand & 1983 & 4.27 & 6.60 & 2.33 & 0 \\
\hline Trinidad \&Tobago & 1971 & 2.07 & 4.80 & 2.73 & 1 \\
\hline Tunisia & 1969 & 2.55 & 6.40 & 3.85 & 0 \\
\hline Tunisia & 1993 & 1.57 & 3.70 & 2.13 & 0 \\
\hline Uganda & 1989 & -0.80 & 3.60 & 4.40 & 0 \\
\hline
\end{tabular}


Table 1 (Continued)

\begin{tabular}{llllll}
\hline Country & Year & $\begin{array}{l}\text { Growth } \\
\text { before } \\
\text { acceleration }\end{array}$ & $\begin{array}{l}\text { Growth } \\
\text { during } \\
\text { acceleration }\end{array}$ & $\begin{array}{l}\text { Difference } \\
\text { in growth } \\
\text { rate }\end{array}$ & $\begin{array}{l}\text { Post crisis } \\
\text { acceleration }\end{array}$ \\
\hline United Kingdom & 1982 & 1.07 & 3.50 & 2.43 & 0 \\
United States & 1961 & 0.90 & 3.90 & 3.00 & 0 \\
Uruguay & 1974 & 1.46 & 4.00 & 2.54 & 0 \\
Zimbabwe & 1963 & 0.21 & 6.60 & 6.39 & 0 \\
Zimbabwe & 1968 & 3.53 & 6.50 & 2.97 & 0 \\
\hline
\end{tabular}

Notes: column (1) indicates the start of the acceleration; column (2) shows the rate of growth in the 8 years preceding the acceleration; column (3) presents the average growth rate during the episode; column (4) presents the difference between column (2) and (3)

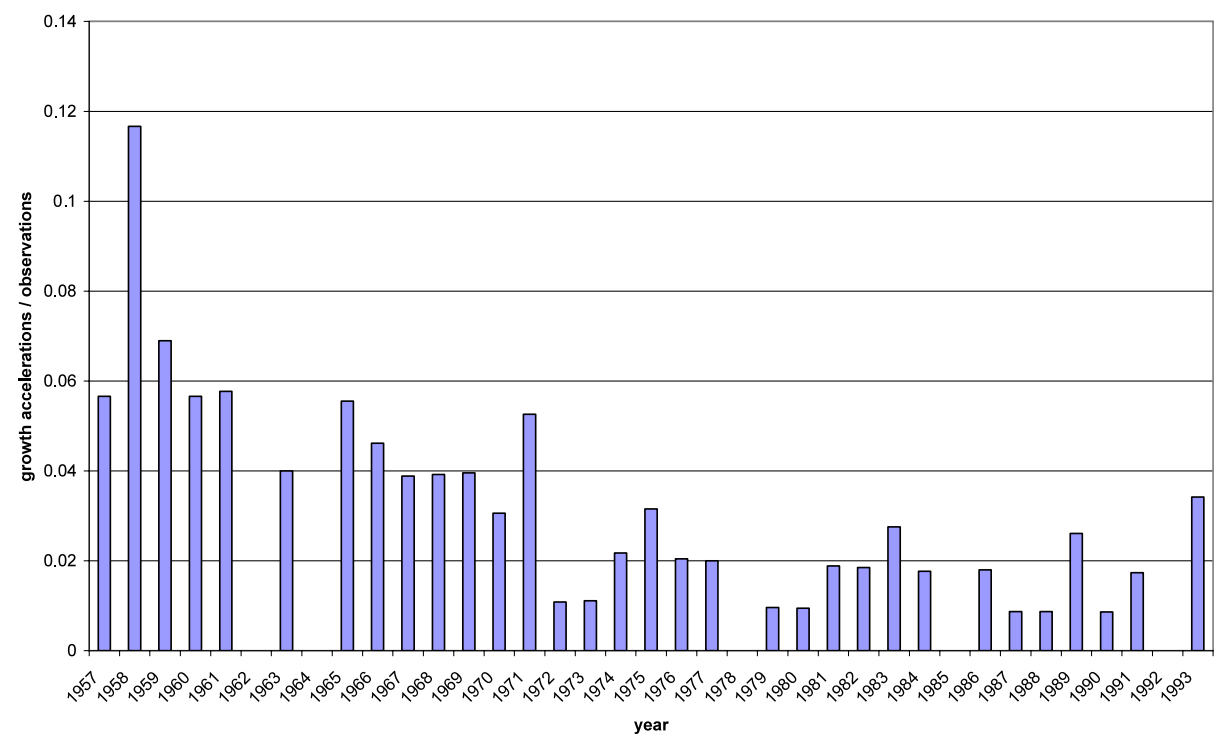

Fig. 2 Growth accelerations over time, 1957-1993. Note: the figure shows the number of growth accelerations per year

\section{Empirical analysis}

We examine whether particular variables trigger growth accelerations. Our dependent variable takes a value of one centered on the timing of the start of a growth acceleration and zero otherwise. ${ }^{6}$ Our dataset consists of 106 countries over the period 1957-1993 of which 60 countries experienced one or more growth accelerations.

Following Giavazzi and Tabellini (2005), Hausmann et al. (2005) and Imam and Salinas (2008), we rely on the index provided by Sachs and Warner (1995) as updated and im-

\footnotetext{
${ }^{6}$ So in case of an acceleration starting in year $t$, the year $t-1$, and $t+1$ also are assigned the value one. See also Hausmann et al. (2005). 
proved upon by Wacziarg and Welch (2008) as our proxy for economic liberalization. This index incorporates a number of structural features (e.g., presence of marketing boards and socialist economic regimes) and the macroeconomic environment (e.g., presence of a large black-market premium for foreign currency), in addition to tariff and non-tariff barriers to trade. The variable included is a dummy that takes the value of 1 during the first 5 years after the country liberalized its markets. ${ }^{7}$ The main advantage of this proxy for economic liberalization is that it is available on a yearly basis, although it is mainly trade oriented. As an alternative, we also use the change in the level of economic freedom (obtained from Gwartney and Lawson 2008) to proxy economic liberalization. ${ }^{8}$

Our regime change variable is taken from the Polity IV dataset of Marshall and Jaggers (2002). In line with the Polity IV manual, a regime change is defined as a three points change in the Polity score in 3 years or less. However, as it is possible that a country has no formal regime for several years, we focus only on those changes, which are followed by a continuation of the same regime for at least one year. Like the economic liberalization dummy, we use a dummy equal to one for the first 5 years after a political regime change and zero otherwise. We differentiate between positive regime changes (i.e., more democracy) and negative regime changes (i.e., more autocracy). In addition, we include the Polity score itself as an explanatory variable to proxy the level of democracy. Finally, we add the duration of a regime defined as the number of years that the current regime is in place, as suggested by Clague et al. (1996).

We decide on the appropriate panel data model using the test proposed by Hausman (1978). The null-hypothesis is that all country fixed effects equal zero. Using the estimates of a conditional fixed effects logit (CFEL) model (see Chamberlain 1980) and the unrestricted (pooled) logit model, this hypothesis is rejected according to the Hausman test for all model specifications. Hence, CFEL should be preferred. ${ }^{9}$ Furthermore, we examine the presence of time effects in the data. As Fig. 2 suggests that the number of growth accelerations is steadily decreasing over time, we include a linear trend in our model, which turns out to be significant in almost all specifications. ${ }^{10}$

Table 2 contains the estimation results. The results reported in columns (1)-(7) are based on the full sample, while columns (8)-(14) exclude those episodes that started just after an economic crisis. As it seems likely that economic growth picks up after a crisis, we want to make sure that our results are not driven by the inclusion of this kind of 'economic recovery' acceleration. ${ }^{11}$ In case the growth rate in the 2 years before the growth acceleration is smaller

\footnotetext{
${ }^{7}$ Rodríguez and Rodrik (2001) have criticized this measure. They argue that some criteria, like black market premiums and export marketing boards, disproportionally determine the outcome of a country being open or closed. Wacziarg and Welch (2008) acknowledge this limitation in the case of their cross-sectional openness measure, but also show that this critique does not hold for the dating of trade liberalization. In our analysis, we only focus on the latter as we are interested only in the timing of trade liberalization.

${ }^{8}$ Although this measure might be a better proxy for economic liberalization, it is available only on at five-year intervals for a sub-period of our sample thereby severely limiting the available observations in our analysis.

${ }^{9}$ As a robustness check, we also estimated our models using a linear probability model with fixed effects. It turns out that the results are very similar to the conditional fixed effects logit results. The results are available on request.

${ }^{10}$ We also considered the inclusion of time effects in our model as growth accelerations might be triggered by, for instance, world economic growth. However, F-tests examining the hypothesis that all time effects equal 0 could not be rejected for most specifications. Besides, the inclusion of a linear trend consumes less degrees of freedom.

${ }^{11}$ See, for example, Fig. 1 in which we illustrate the case of Chile. There, the first acceleration followed a period in which income per capita dropped substantially (16\%). There are 14 accelerations that have started after an economic crisis. They are indicated in column 5 of Table 1.
} 
Table 2 Estimation results: base model

\begin{tabular}{|c|c|c|c|c|c|c|c|}
\hline & \multicolumn{7}{|c|}{ Dependent variable: growth a Including post-crisis periods } \\
\hline & $(1)$ & (2) & (3) & (4) & $(5)$ & $(6)$ & (7) \\
\hline Time trend & $\begin{array}{l}-0.061 \\
(7.23)^{* * *}\end{array}$ & $\begin{array}{l}-0.049 \\
(5.46)^{* * *}\end{array}$ & $\begin{array}{l}-0.046 \\
(4.88)^{* * *}\end{array}$ & $\begin{array}{l}-0.036 \\
(3.62)^{* * *}\end{array}$ & $\begin{array}{l}-0.032 \\
(3.14)^{* * *}\end{array}$ & $\begin{array}{l}-0.030 \\
(2.81)^{\text {*** }}\end{array}$ & $\begin{array}{l}-0.027 \\
(2.45)^{* * *}\end{array}$ \\
\hline Economic reform & $\begin{array}{c}1.004 \\
(3.88)^{* * *}\end{array}$ & $\begin{array}{c}0.897 \\
(3.46)^{* * *}\end{array}$ & $\begin{array}{c}0.887 \\
(3.40)^{* * *}\end{array}$ & $\begin{array}{c}0.877 \\
(3.37)^{* * *}\end{array}$ & $\begin{array}{c}0.870 \\
(3.30)^{* * *}\end{array}$ & $\begin{array}{c}0.820 \\
(3.12)^{* * *}\end{array}$ & $\begin{array}{c}0.815 \\
(3.10)^{* * *}\end{array}$ \\
\hline Regime change & $\begin{array}{c}-0.006 \\
(0.02)\end{array}$ & & $\begin{array}{c}-0.408 \\
(1.58)\end{array}$ & & $\begin{array}{l}-0.789 \\
(2.91)^{* * *}\end{array}$ & & \\
\hline Positive regime change & & & & $\begin{array}{l}-1.162 \\
(3.37)^{* * *}\end{array}$ & & $\begin{array}{l}-1.556 \\
(4.21)^{\text {*** }}\end{array}$ & \\
\hline Negative regime chang & & & & $\begin{array}{c}0.326 \\
(1.06)\end{array}$ & & $\begin{array}{c}0.035 \\
(0.10)\end{array}$ & \\
\hline Regime duration & & $\begin{array}{l}-0.031 \\
(3.05)^{* * *}\end{array}$ & $\begin{array}{l}-0.040 \\
(3.43)^{* * *}\end{array}$ & $\begin{array}{l}-0.048 \\
(4.04)^{* * *}\end{array}$ & $\begin{array}{l}-0.065 \\
(4.83)^{* * *}\end{array}$ & $\begin{array}{l}-0.064 \\
(4.71)^{\text {*** }}\end{array}$ & $\begin{array}{l}-0.068 \\
(4.83)^{* * *}\end{array}$ \\
\hline Democracy & & & & & $\begin{array}{l}-0.050 \\
(2.27)^{* *}\end{array}$ & $\begin{array}{r}-0.003 \\
(0.10)\end{array}$ & $\begin{array}{c}-0.014 \\
(0.50)\end{array}$ \\
\hline Regtrans $=-2$ & & & & & & $\begin{array}{c}-0.021 \\
(0.06)\end{array}$ & \\
\hline Regtrans $=-1$ & & & & & & $\begin{array}{c}0.223 \\
(0.28)\end{array}$ & \\
\hline Regtrans $=1$ & & & & & & $\begin{array}{l}-2.034 \\
(3.06)^{* * *}\end{array}$ & \\
\hline Regtrans $=2$ & & & & & & $\begin{array}{c}-0.806 \\
(0.97)\end{array}$ & \\
\hline Regtrans $=3$ & & & & & & $\begin{array}{l}-1.469 \\
(3.31)^{* * *}\end{array}$ & \\
\hline Observations & 1235 & 1239 & 1235 & 1235 & 1205 & 1205 & 1209 \\
\hline Countries & 48 & 48 & 48 & 48 & 48 & 48 & 48 \\
\hline Pseudo $R$-squared & 0.08 & 0.09 & 0.09 & 0.11 & 0.11 & 0.12 & 0.12 \\
\hline
\end{tabular}

than $-10 \%$, we define it as post-crisis growth acceleration. ${ }^{12}$ It can be immediately observed that the results for the two samples are very similar.

In all regressions, the economic liberalization variable is always included. In contrast to the results reported by Hausmann et al. (2005), we find that the effect of economic liberalization on the probability for growth accelerations is highly significant in all specifications. In columns (2)-(7) and (9)-(14), regime duration is added. This variable also is always significant. The longer a regime has been in place, the less likely growth accelerations will occur.

However, the results for political regime changes are less clear. In columns (1) and (8), the coefficient of the political regime changes variable is not significantly different from

\footnotetext{
${ }^{12}$ Using a threshold of $-5 \%$, we find 13 additional post crisis growth accelerations. If a threshold of $-15 \%$ is used, we find only four such episodes.
} 
Table 2 (Continued)

\begin{tabular}{|c|c|c|c|c|c|c|c|}
\hline & \multicolumn{7}{|c|}{ Excluding post crisis periods } \\
\hline & $(8)$ & (9) & $(10)$ & $(11)$ & (12) & (13) & (14) \\
\hline Time trend & $\begin{array}{l}-0.061 \\
(6.55)^{* * *}\end{array}$ & $\begin{array}{l}-0.044 \\
(4.43)^{\text {*** }}\end{array}$ & $\begin{array}{l}-0.041 \\
(3.97)^{\text {*** }}\end{array}$ & $\begin{array}{l}-0.029 \\
(2.59)^{\text {*** }}\end{array}$ & $\begin{array}{c}-0.023 \\
(1.92)^{*}\end{array}$ & $\begin{array}{r}-0.020 \\
(1.62)\end{array}$ & $\begin{array}{r}-0.013 \\
(1.02)\end{array}$ \\
\hline Economic reform & $\begin{array}{l}1.175 \\
(4.16)^{* * *}\end{array}$ & $\begin{array}{c}1.025 \\
(3.60)^{\text {*** }}\end{array}$ & $\begin{array}{l}1.026 \\
(3.59)^{\text {*** }}\end{array}$ & $\begin{array}{l}1.002 \\
(3.51)^{* * *}\end{array}$ & $\begin{array}{l}1.024 \\
(3.54)^{* * *}\end{array}$ & $\begin{array}{c}0.968 \\
(3.36)^{\text {*** }}\end{array}$ & $\begin{array}{l}0.946 \\
(3.27)^{\text {*** }}\end{array}$ \\
\hline Regime change & $\begin{array}{l}0.208 \\
(0.80)\end{array}$ & & $\begin{array}{c}-0.330 \\
(1.17)\end{array}$ & & $\begin{array}{c}-0.696 \\
(2.39)^{* *}\end{array}$ & & \\
\hline Positive regime change & & & & $\begin{array}{l}-1.159 \\
(3.10)^{* * *}\end{array}$ & & $\begin{array}{l}-1.453 \\
(3.68)^{* * *}\end{array}$ & \\
\hline Negative regime change & & & & $\begin{array}{c}0.490 \\
(1.45)\end{array}$ & & $\begin{array}{c}0.121 \\
(0.31)\end{array}$ & \\
\hline Regime duration & & $\begin{array}{l}-0.044 \\
(3.80)^{* * *}\end{array}$ & $\begin{array}{l}-0.051 \\
(3.88)^{\text {*** }}\end{array}$ & $\begin{array}{l}-0.061 \\
(4.54)^{* * *}\end{array}$ & $\begin{array}{l}-0.083 \\
(5.34)^{* * *}\end{array}$ & $\begin{array}{l}-0.082 \\
(5.20)^{\text {*** }}\end{array}$ & $\begin{array}{l}-0.090 \\
(5.45)^{* * *}\end{array}$ \\
\hline Democracy & & & & & $\begin{array}{l}-0.072 \\
(2.88)^{* * *}\end{array}$ & $\begin{array}{c}-0.026 \\
(0.86)\end{array}$ & $\begin{array}{r}-0.045 \\
(1.43)\end{array}$ \\
\hline Regtrans $=-2$ & & & & & & $\begin{array}{c}0.042 \\
(0.10)\end{array}$ & \\
\hline Regtrans $=-1$ & & & & & & $\begin{array}{c}0.189 \\
(0.24)\end{array}$ & \\
\hline Regtrans $=1$ & & & & & & $\begin{array}{l}-2.111 \\
(2.98)^{* * *}\end{array}$ & \\
\hline Regtrans $=2$ & & & & & & $\begin{array}{c}-0.096 \\
(0.11)\end{array}$ & \\
\hline Regtrans $=3$ & & & & & & $\begin{array}{l}-1.409 \\
(2.97)^{\text {*** }}\end{array}$ & \\
\hline Observations & 1070 & 1073 & 1070 & 1070 & 1045 & 1045 & 1048 \\
\hline Countries & 42 & 42 & 42 & 42 & 42 & 42 & 42 \\
\hline Pseudo $R$-squared & 0.08 & 0.10 & 0.10 & 0.12 & 0.12 & 0.14 & 0.14 \\
\hline
\end{tabular}

Absolute value of $z$ statistics in parentheses ${ }^{*}$ significant at $10 \% ;{ }^{* *}$ significant at $5 \%$; ${ }^{* * *}$ significant at $1 \%$

zero. ${ }^{13}$ However, columns (4) and (11) suggest that positive regime changes do matter, i.e., a move toward democracy reduces the likelihood of a growth acceleration.

To examine the effect of democracy further, we add in columns (5)-(7) and (12)-(14) our democracy variable as explanatory variable. Its coefficient is always negative, i.e., growth accelerations are more likely under autocracy, while in columns (5) and (12) its coefficient is

\footnotetext{
${ }^{13}$ Our method to identify political regime changes is fully in line with the approach suggested by Hausmann et al. (2005). However, as Jong-A-Pin and De Haan (2008) pointed out, Hausmann et al. (2005) made a serious mistake in coding regime changes. Jong-A-Pin and De Haan (2008) use the filter as proposed by Hausmann et al. (2005) to identify growth accelerations and they also find that political regime changes are not related to growth accelerations. So, our different findings with respect to the impact of regime changes on growth accelerations are not caused by the use of our proposed filter.
} 
significantly different from zero. If we add positive and negative regime changes (columns (6) and (13)), the democracy variable becomes insignificant, but positive regime changes remain significant with a negative coefficient. In columns (7) and (14), we disaggregate the regime changes in five categories, using the Polity IV variable Regtrans. If Regtrans $=3$, there is a six points or greater increase in the Polity score over a period of 3 years or less. If Regtrans $=2$, there is a three to five point increase in the Polity score over a period of 3 years or less. If Regtrans $=1$, there is a three or more point increase in the Polity score without a shift in regime type, while a score of -1 indicates a three or more point decrease in the Polity score. A value of -2 indicates a six or more points decrease in the Polity score. In line with our previous findings, it turns out that the coefficients of variables reflecting positive regime changes are negative and significant (except for Regtrans $=2$, which probably reflects that there are only a few observations for this variable). If post-crisis periods are excluded, the democracy variable also becomes significant (column 14). So all this evidence suggests that (a move towards) more democracy reduces the likelihood of economic growth accelerations.

\section{Robustness analysis}

To check the robustness of our results, we run several variants of our base model. The results are reported in Table 3 and Table 4. Again, we show results for the full sample (Table 3) and for the sample in which episodes started just after an economic crisis are exluded (Table 4).

First, we replace the regime change variable by two alternative indicators based on the work of Przeworski et al. (2000) and Vanhanen (2000). We define a regime change if these authors indicate that a regime switches from democracy to autocracy and vice versa. In the full sample, both regime change variables are hardly significant. Only when we use the Przeworski regime change variable do we find that negative regime changes increase the probability that growth will accelerate. If we exclude the post-crisis periods, the results become more pronounced. For both regime change variables, we find that changes toward more autocracy increase the probability of a growth acceleration.

Second, we add several control variables to the base model as suggested by Hausmann et al. (2005). In column (5) of Tables 3 and 4, we add a dummy for financial liberalization, while in column (6) we incorporate terms of trade. Unfortunately, the use of additional control variables decreases the sample size. It can be seen that adding the terms of trade variable or the financial liberalization measure affects the result for the economic liberalization variable, which becomes insignificant or less significant in the full sample. This result could be driven by the fact that a number of countries drop from the sample all of which had experienced economic liberalization just before a growth acceleration. ${ }^{14}$ When we include variables that capture characteristics of the political environment such as the death of a political leader and its interaction ${ }^{15}$ with the tenure of the political leader (following Jones and Olken (2008); results are in column (7) of Tables 3 and 4), or the end of a (civil) war (column (8) of Tables 3 and 4), we obtain the same results as in the base model. Economic liberalization, the duration of the regime, and (a move toward) more democracy all significantly affect the likelihood of growth accelerations.

\footnotetext{
${ }^{14}$ This happened in Denmark, Guinea-Bissau, South-Korea, Morocco, Poland, Tunisia, Taiwan, and Uganda.

${ }^{15}$ Note that the constitutive term of the tenure of the political leader cannot be included in the model because of perfect collinearity with the interaction term. As Brambor et al. (2006) point out omitting the constitutive term may bias the estimates.
} 


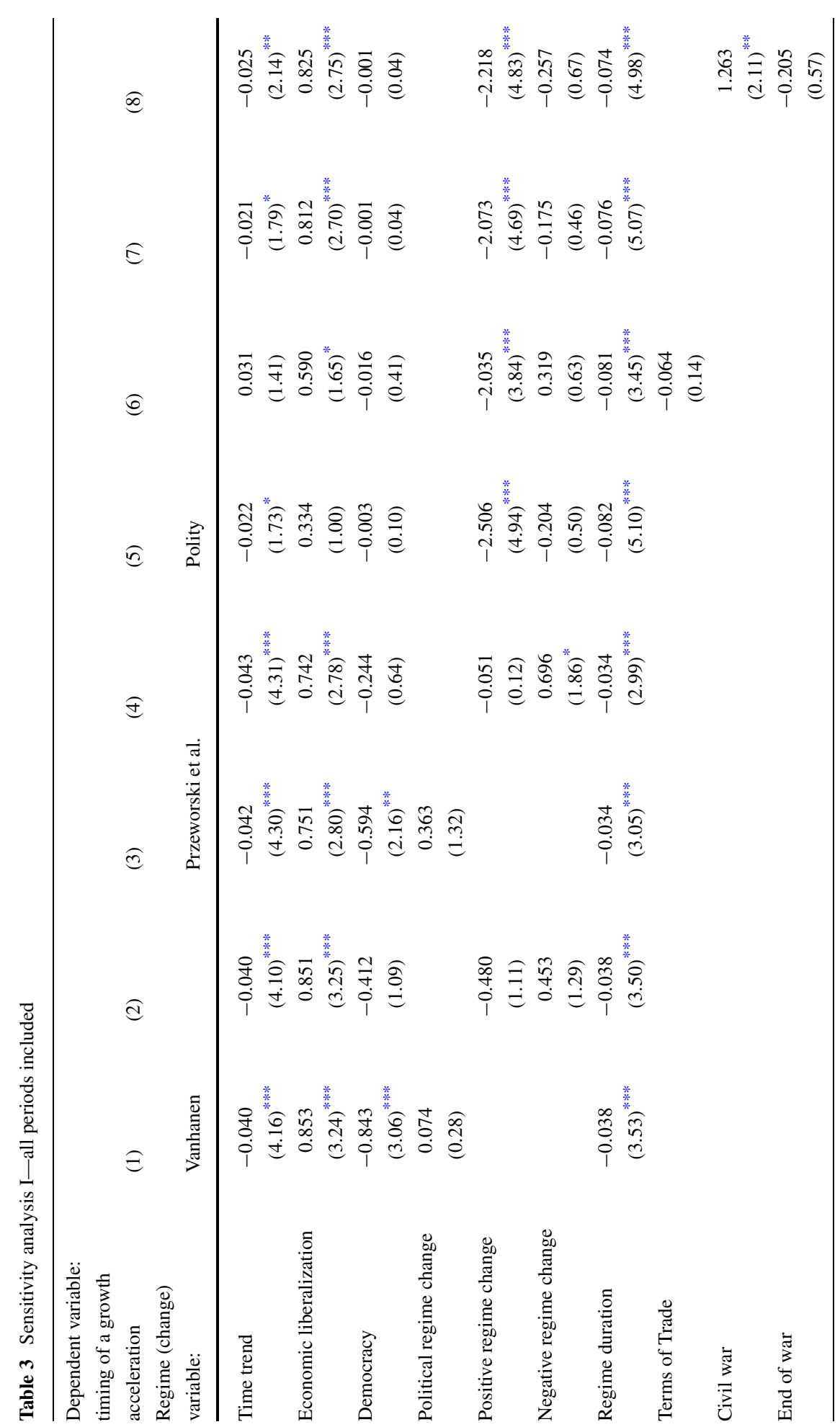




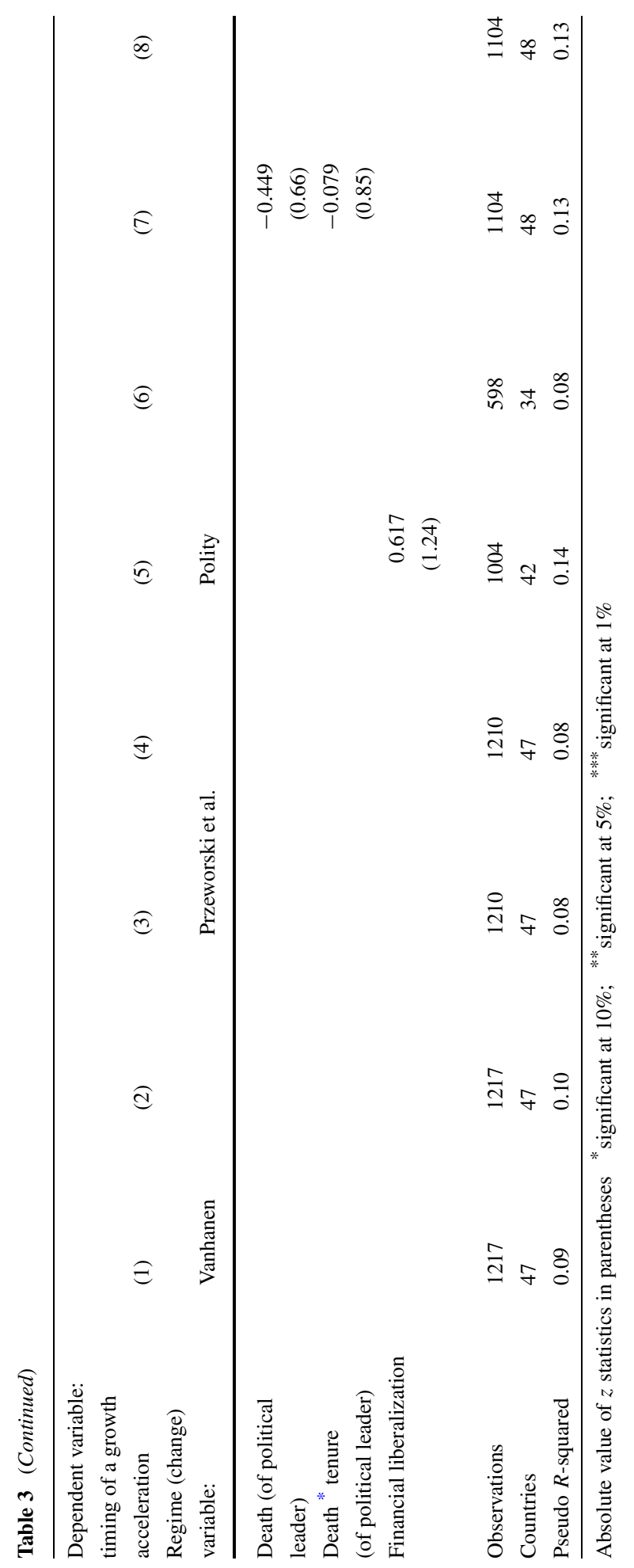




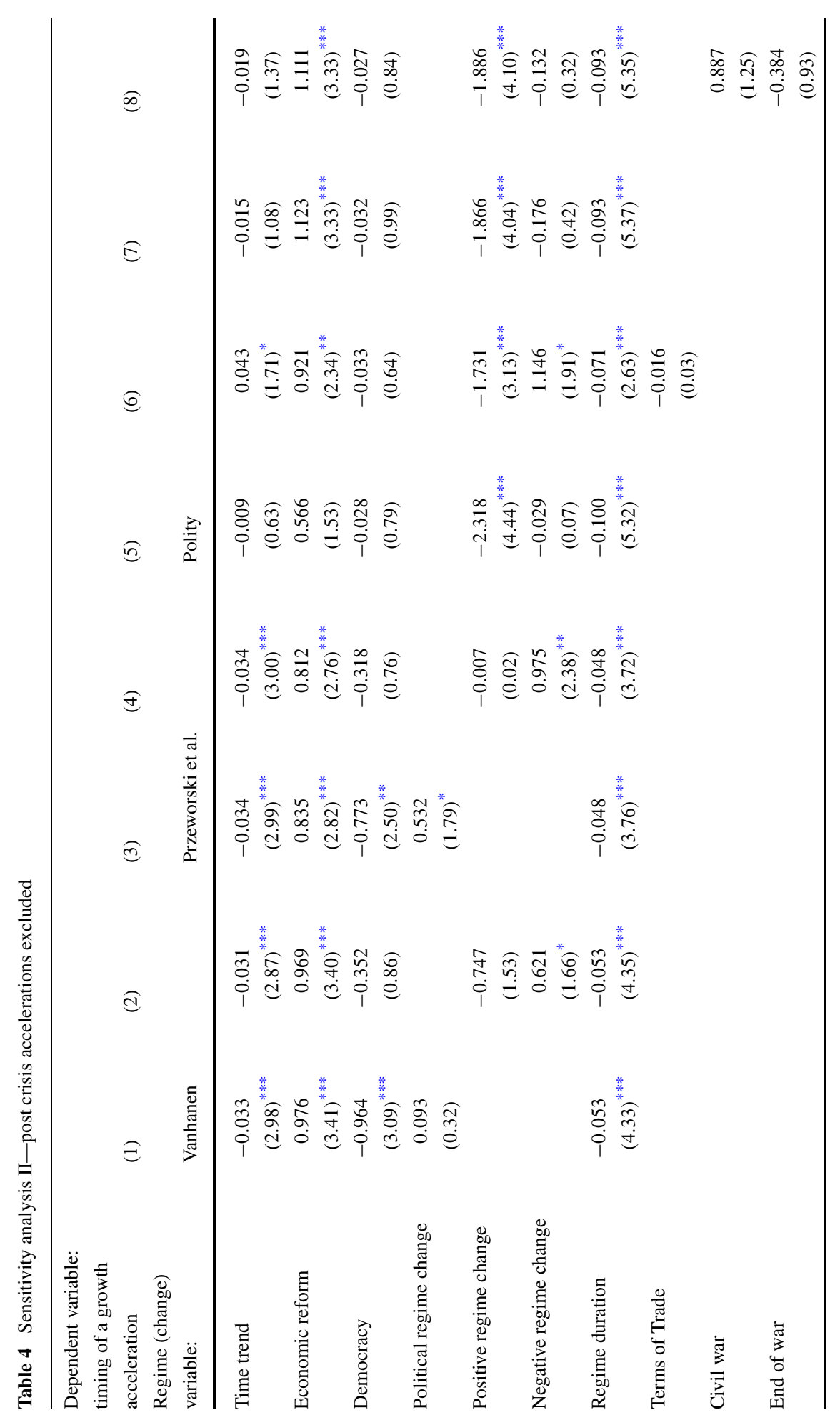




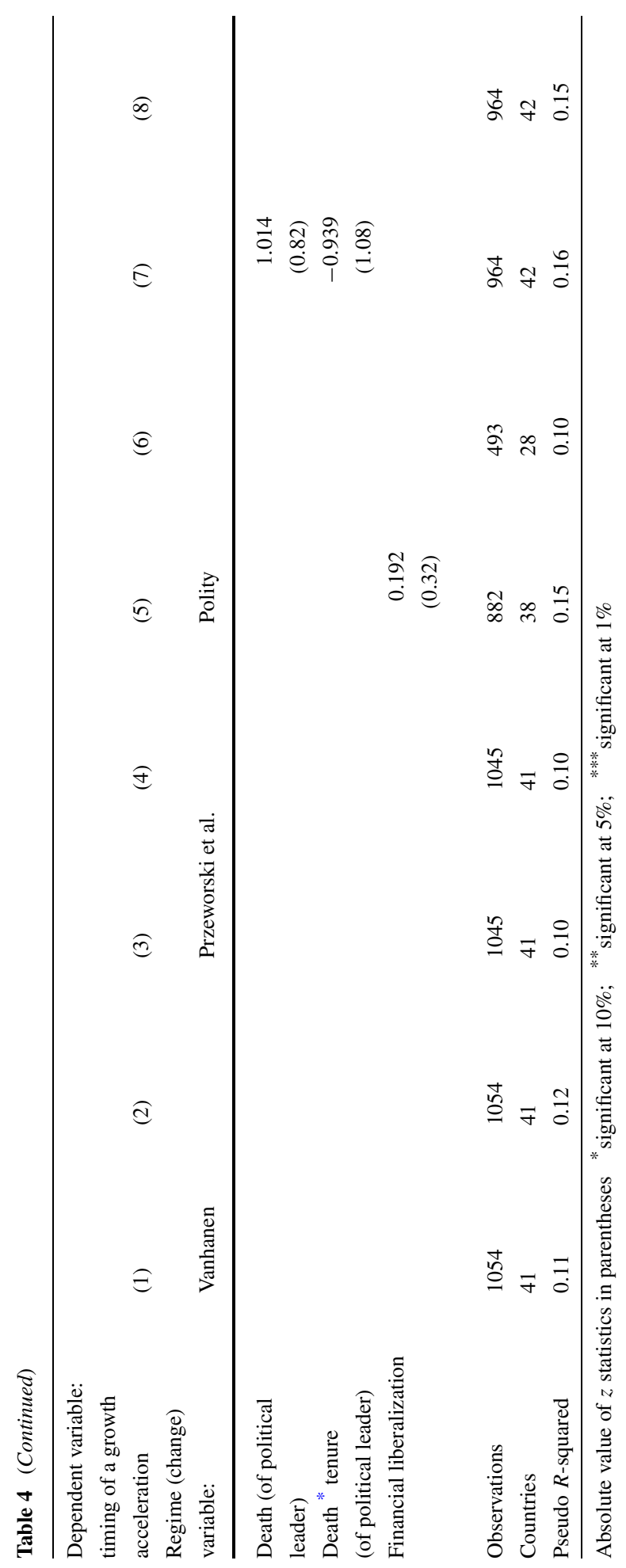




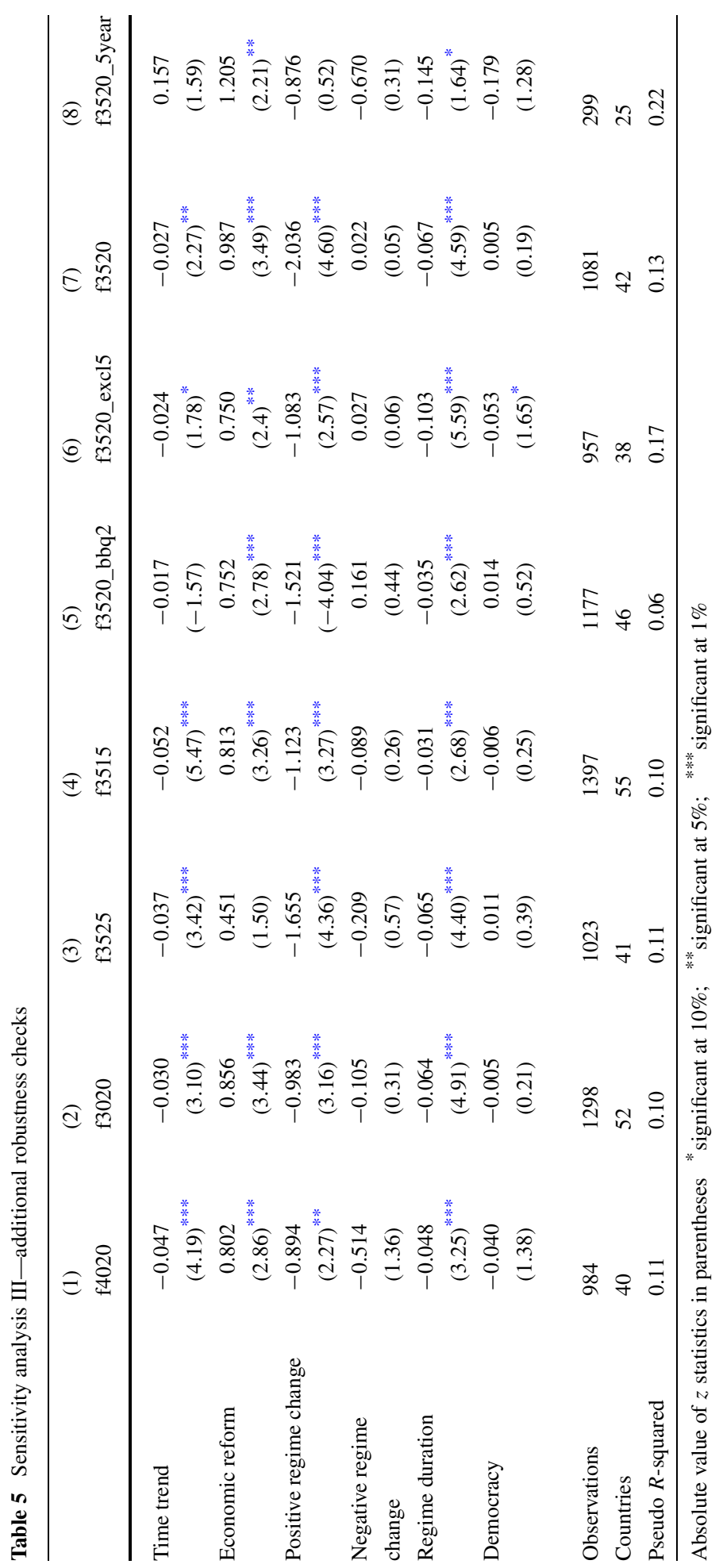


Third, we run several regressions using alternative restrictions on our filter to identify growth accelerations. As a benchmark, we use specification 5 of Table 2. In column (1) of Table 5, we increase the requirement of rapid growth to $4 \mathrm{ppa}$, while we decrease it to 3 ppa in column (2). Alternatively, in columns (3) and (4), we change the requirement that economic growth increases relative to the previous period to $2.5 \mathrm{ppa}$ and $1.5 \mathrm{ppa}$, respectively. In column (5), we impose the condition that economic growth at the beginning of the acceleration should be substantial. That is, we require that economic growth during the first 2 years of the growth acceleration exceeds economic growth in the 2 years before the start of the acceleration. In column (6), we focus again on growth accelerations that are not preceded by a period of economic crisis. However, here we use a milder restriction and only focus on those cases that are not preceded by a 2-year period in which economic growth was lower than $5 \%$.

Finally, we provide two more robustness checks. In column (7) of Table 5, we exclude all East Asian countries from our sample to check whether our results are driven by the "East Asian Miracle" countries. Finally, we replace our economic liberalization indicator by the first difference of the economic freedom index of Gwartney and Lawson (2008). This index is available only from 1970 onward on a 5-year interval causing a large drop in the number of observations that can be analyzed. To implement this index in our model and to cope with the scattered availability of data, we estimate a pooled logit model. More specifically, we examine whether economic growth accelerations are preceded by increases in the economic freedom index in the 5-year interval in the preceding 5-year period to minimize endogeneity problems. For example, Chile's first acceleration started in 1983. Hence, we examine whether this acceleration was preceded by an increase in economic freedom in the period 1975-1979.

All results presented in Table 5 show that our estimation results are, in general, robust to the alternative specifications as described above.

\section{Concluding comments}

Due to the fixation on long-run differences in growth, empirical research on economic growth has underestimated the importance of instability and volatility in growth rates, especially in developing countries. Traditional cross-country and panel growth models are not well suited for using information provided by the time dimension. Periods chosen in panel models are often justified only on the grounds that data were available at those frequencies or the researcher wanted to divide the whole period into equal chunks. These periods are unlikely to tease out information provided by the development of variables over time. If, for instance, there is a high growth rate in the first 5 years and a low growth rate in the second half of the 10-year period, the period average will be rather uninformative (De Haan 2007).

The approach suggested by Hausmann et al. (2005) uses the information provided by the time dimension, focusing on turning points in growth performance, and examining instances of rapid acceleration in economic growth that are sustained. Building upon that seminal work, we make various contributions. First, we improve upon the filter used by Hausmann et al. to identify growth accelerations. Even though we focus on the same sample as used by Hausmann et al. (2005), there are substantial differences between accelerations identified by their our filter and ours. Second, we test for country fixed effects and, based on the testing outcomes, use conditional fixed effects logistic regressions instead of (pooled) probit regressions. Third, we do not focus only on economic liberalization and (the direction of) regime changes, but also examine the role of the regime in place and its duration. Finally, we 
investigate the robustness of our results using alternative regime and economic liberalization indicators.

Our main findings are as follows. First, we find that economic growth accelerations are preceded by economic liberalization. This result does not depend on the use of the Sachs/Warner/Wacziarg/Welch indicator of economic liberalization: this result also holds when we use the change in the Economic Freedom indicator of Gwartney and Lawson (2008). Second, we find that political regimes changes in general do not precede growth accelerations. However, our results show that regime changes toward more democracy (according to Polity IV) reduce the likelihood of a growth acceleration. These results stand in contrast to the findings of Hausmann et al. (2005). As we have shown earlier (see Jong-APin and De Haan 2008), part of the difference in our results can be explained by the fact that Hausmann et al. were led astray by a coding error in the way they constructed their indicator of political regime change. However, our improved filter and empirical model make our findings concerning the negative impact of changes toward more democracy and economic liberalization more pronounced. We also find that growth accelerations are less likely to happen the longer a political regime-be it a democracy or an autocracy-has been in place. This finding is in line with Olson's (1982) sclerosis view of government. Although this finding is in contrast with the notion that political instability is, on average, detrimental to growth, it is in line with recent findings that a single leadership (or regime) change may be a necessary condition for a country to start a period of economic growth (Jones and Olken 2005; Jong-A-Pin and Yu 2010).

Acknowledgements We like to thank participants in seminars at the Free University in Brussels, the University of Groningen, ETH Zürich, and the World Public Choice Society Meeting 2007 for helpful comments. We are also thankful to two referees for their helpful suggestions on a previous version of the paper. The views expressed do not necessarily coincide with the views of the Netherlands Bank.

Open Access This article is distributed under the terms of the Creative Commons Attribution Noncommercial License which permits any noncommercial use, distribution, and reproduction in any medium, provided the original author(s) and source are credited.

\section{Appendix: A comparison with the filter of Hausmann et al. (2005)}

We use the same GDP data as Hausmann et al. (2005), so that differences in dating growth accelerations are not caused by the use of different data sets. Table 6 reports the growth rate before the start of the growth accelerations identified by Hausmann et al. (2005), the growth rate in the first year of the acceleration and the 8-year growth average according to data from the Penn World Tables 6.1.

Table 6 shows that 18 growth acceleration episodes as identified by Hausmann et al. have a negative growth rate in the first year of the acceleration. Furthermore, 27 of the identified episodes have a higher growth rate in the year before the acceleration than at the start of the acceleration. Finally, in 10 episodes, growth in the year before the acceleration is higher than the average growth rate during the entire acceleration. On the basis of these figures, 
Table 6 Growth accelerations according to Hausmann et al. (2005)

\begin{tabular}{|c|c|c|c|c|c|c|c|}
\hline Country & $\begin{array}{l}(1) \\
\text { Year }\end{array}$ & $\begin{array}{l}(2) \\
\text { Growth in } \\
\text { year before } \\
\text { acceleration }\end{array}$ & $\begin{array}{l}\text { (3) } \\
\text { Growth in } \\
\text { first year of } \\
\text { acceleration }\end{array}$ & $\begin{array}{l}\text { (4) } \\
\text { Average } \\
\text { growth } \\
\text { during } \\
\text { acceleration }\end{array}$ & $\begin{array}{l}(5) \\
\text { Growth } \\
\text { before > } \\
\text { growth at } \\
\text { start? }\end{array}$ & $\begin{array}{l}\text { (6) } \\
\text { Growth } \\
\text { before > } \\
\text { growth } \\
\text { during? }\end{array}$ & $\begin{array}{l}(7) \\
\text { Growth } \\
\text { at start } \\
<0 \text { ? }\end{array}$ \\
\hline Algeria & 1975 & 1.6 & 10.7 & 4.2 & $\mathrm{n}$ & $\mathrm{n}$ & $\mathrm{n}$ \\
\hline Argentina & 1963 & -6.1 & 7.7 & 3.6 & $\mathrm{n}$ & $\mathrm{n}$ & $\mathrm{n}$ \\
\hline Argentina & 1990 & -6.0 & 9.8 & 6.1 & $\mathrm{n}$ & $\mathrm{n}$ & $\mathrm{n}$ \\
\hline Australia & 1961 & -1.7 & 4.8 & 3.8 & $\mathrm{n}$ & $\mathrm{n}$ & $\mathrm{n}$ \\
\hline Belgium & 1959 & 3.8 & 5.4 & 4.5 & $\mathrm{n}$ & $\mathrm{n}$ & $\mathrm{n}$ \\
\hline Botswana & 1969 & 5.1 & -5.1 & 11.7 & $\mathrm{y}$ & $\mathrm{n}$ & $\mathrm{y}$ \\
\hline Brazil & 1967 & 2.5 & 8.4 & 7.8 & $\mathrm{n}$ & $\mathrm{n}$ & $\mathrm{n}$ \\
\hline Canada & 1962 & 5.1 & 3.4 & 3.6 & $\mathrm{y}$ & $\mathrm{y}$ & $\mathrm{n}$ \\
\hline Chad & 1973 & -8.3 & -4.6 & 7.3 & $\mathrm{n}$ & $\mathrm{n}$ & $\mathrm{y}$ \\
\hline Chile & 1986 & 3.1 & 3.7 & 5.5 & $\mathrm{n}$ & $\mathrm{n}$ & $\mathrm{n}$ \\
\hline China & 1978 & -1.1 & 10.6 & 6.7 & $\mathrm{n}$ & $\mathrm{n}$ & $\mathrm{n}$ \\
\hline China & 1990 & 7.0 & 10.6 & 8.0 & $\mathrm{n}$ & $\mathrm{n}$ & $\mathrm{n}$ \\
\hline Colombia & 1967 & 0.8 & 2.9 & 4.0 & $\mathrm{n}$ & $\mathrm{n}$ & $\mathrm{n}$ \\
\hline Comoros & 1972 & -2.8 & 0.6 & 5.3 & $\mathrm{n}$ & $\mathrm{n}$ & $\mathrm{n}$ \\
\hline Congo Rep. & 1969 & 9.0 & 12.2 & 5.4 & $\mathrm{n}$ & $\mathrm{y}$ & $\mathrm{n}$ \\
\hline Congo Rep. & 1978 & 7.9 & 13.7 & 8.2 & $\mathrm{n}$ & $\mathrm{n}$ & $\mathrm{n}$ \\
\hline Denmark & 1957 & 4.0 & 0.5 & 5.3 & $\mathrm{y}$ & $\mathrm{n}$ & $\mathrm{n}$ \\
\hline Dominican Rep. & 1969 & 5.4 & 13.3 & 5.5 & $\mathrm{n}$ & $\mathrm{n}$ & $\mathrm{n}$ \\
\hline Dominican Rep. & 1992 & 4.2 & 3.8 & 6.3 & $\mathrm{y}$ & $\mathrm{n}$ & $\mathrm{n}$ \\
\hline Ecuador & 1970 & 4.2 & 2.9 & 8.4 & $\mathrm{y}$ & $\mathrm{n}$ & $\mathrm{n}$ \\
\hline Egypt & 1976 & 10.3 & 9.8 & 4.7 & $\mathrm{y}$ & $\mathrm{y}$ & $\mathrm{n}$ \\
\hline Finland & 1958 & -2.1 & 7.1 & 5.0 & $\mathrm{n}$ & $\mathrm{n}$ & $\mathrm{n}$ \\
\hline Finland & 1967 & 1.3 & 0.6 & 5.6 & $\mathrm{y}$ & $\mathrm{n}$ & $\mathrm{n}$ \\
\hline Finland & 1992 & -7.8 & -4.3 & 2.8 & $\mathrm{n}$ & $\mathrm{n}$ & $\mathrm{y}$ \\
\hline Ghana & 1965 & -21.7 & 22.7 & 8.3 & $\mathrm{n}$ & $\mathrm{n}$ & $\mathrm{n}$ \\
\hline Guinea-Bissau & 1969 & -1.7 & -27.8 & 8.1 & $\mathrm{y}$ & $\mathrm{n}$ & $\mathrm{y}$ \\
\hline Guinea-Bissau & 1988 & -5.4 & -1.6 & 5.2 & $\mathrm{n}$ & $\mathrm{n}$ & $\mathrm{y}$ \\
\hline Haiti & 1990 & 1.9 & 11.6 & 12.7 & $\mathrm{n}$ & $\mathrm{n}$ & $\mathrm{n}$ \\
\hline India & 1982 & 3.2 & 5.3 & 3.9 & $\mathrm{n}$ & $\mathrm{n}$ & $\mathrm{n}$ \\
\hline Indonesia & 1967 & -1.6 & 9.4 & 5.5 & $\mathrm{n}$ & $\mathrm{n}$ & $\mathrm{n}$ \\
\hline Indonesia & 1987 & 2.5 & 4.0 & 5.5 & $\mathrm{n}$ & $\mathrm{n}$ & $\mathrm{n}$ \\
\hline Ireland & 1958 & 0.0 & 4.8 & 3.7 & $\mathrm{n}$ & $\mathrm{n}$ & $\mathrm{n}$ \\
\hline Ireland & 1985 & 2.5 & -0.6 & 5.0 & $\mathrm{y}$ & $\mathrm{n}$ & $\mathrm{y}$ \\
\hline Israel & 1957 & 3.6 & 3.2 & 5.3 & $\mathrm{y}$ & $\mathrm{n}$ & $\mathrm{n}$ \\
\hline Israel & 1967 & -6.0 & 17.2 & 7.2 & $\mathrm{n}$ & $\mathrm{n}$ & $\mathrm{n}$ \\
\hline Japan & 1958 & 3.4 & 8.4 & 9.0 & $\mathrm{n}$ & $\mathrm{n}$ & $\mathrm{n}$ \\
\hline Jordan & 1973 & -1.5 & -1.7 & 9.1 & $\mathrm{y}$ & $\mathrm{n}$ & $\mathrm{y}$ \\
\hline Rep. Korea & 1962 & -0.4 & 8.9 & 6.9 & $\mathrm{n}$ & $\mathrm{n}$ & $\mathrm{n}$ \\
\hline Rep. Korea & 1984 & 7.2 & 5.3 & 8.0 & $\mathrm{y}$ & $\mathrm{n}$ & $\mathrm{n}$ \\
\hline Lesotho & 1971 & 3.4 & -0.6 & 5.3 & $\mathrm{y}$ & $\mathrm{n}$ & $\mathrm{y}$ \\
\hline
\end{tabular}


Table 6 (Continued)

\begin{tabular}{|c|c|c|c|c|c|c|c|}
\hline Country & $\begin{array}{l}(1) \\
\text { Year }\end{array}$ & $\begin{array}{l}\text { (2) } \\
\text { Growth in } \\
\text { year before } \\
\text { acceleration }\end{array}$ & $\begin{array}{l}\text { (3) } \\
\text { Growth in } \\
\text { first year of } \\
\text { acceleration }\end{array}$ & $\begin{array}{l}\text { (4) } \\
\text { Average } \\
\text { growth } \\
\text { during } \\
\text { acceleration }\end{array}$ & $\begin{array}{l}(5) \\
\text { Growth } \\
\text { before > } \\
\text { growth at } \\
\text { start? }\end{array}$ & $\begin{array}{l}\text { (6) } \\
\text { Growth } \\
\text { before > } \\
\text { growth } \\
\text { during? }\end{array}$ & $\begin{array}{l}(7) \\
\text { Growth } \\
\text { at start } \\
<0 \text { ? }\end{array}$ \\
\hline Malawi & 1970 & -9.1 & 21.8 & 3.9 & $\mathrm{n}$ & $\mathrm{n}$ & $\mathrm{n}$ \\
\hline Malawi & 1992 & -10.3 & 12.8 & 4.8 & $\mathrm{n}$ & $\mathrm{n}$ & $\mathrm{n}$ \\
\hline Malaysia & 1970 & 3.3 & 3.2 & 5.1 & $\mathrm{y}$ & $\mathrm{n}$ & $\mathrm{n}$ \\
\hline Malaysia & 1988 & 6.2 & 6.4 & 5.7 & $\mathrm{n}$ & $\mathrm{y}$ & $\mathrm{n}$ \\
\hline Mali & 1972 & 2.8 & -3.6 & 3.8 & $\mathrm{y}$ & $\mathrm{n}$ & $\mathrm{y}$ \\
\hline Mauritius & 1971 & -0.5 & 4.4 & 6.7 & $\mathrm{n}$ & $\mathrm{n}$ & $\mathrm{n}$ \\
\hline Mauritius & 1983 & -0.2 & 2.6 & 5.5 & $\mathrm{n}$ & $\mathrm{n}$ & $\mathrm{n}$ \\
\hline Morocco & 1958 & 5.4 & 1.3 & 7.7 & $\mathrm{y}$ & $\mathrm{n}$ & $\mathrm{n}$ \\
\hline New Zealand & 1957 & 3.4 & -1.3 & 3.8 & $\mathrm{y}$ & $\mathrm{n}$ & $\mathrm{y}$ \\
\hline Nicaragua & 1960 & 6.3 & 3.6 & 4.8 & $\mathrm{y}$ & $\mathrm{y}$ & $\mathrm{n}$ \\
\hline Nigeria & 1957 & -0.6 & 4.2 & 4.3 & $\mathrm{n}$ & $\mathrm{n}$ & $\mathrm{n}$ \\
\hline Nigeria & 1967 & -17.8 & -3.2 & 7.3 & $\mathrm{n}$ & $\mathrm{n}$ & $\mathrm{y}$ \\
\hline Norway & 1991 & 2.5 & 2.5 & 3.7 & $\mathrm{n}$ & $\mathrm{n}$ & $\mathrm{n}$ \\
\hline Pakistan & 1962 & 1.7 & 4.0 & 4.8 & $\mathrm{n}$ & $\mathrm{n}$ & $\mathrm{n}$ \\
\hline Pakistan & 1979 & -1.7 & 7.3 & 4.6 & $\mathrm{n}$ & $\mathrm{n}$ & $\mathrm{n}$ \\
\hline Panama & 1959 & -0.7 & 9.7 & 5.4 & $\mathrm{n}$ & $\mathrm{n}$ & $\mathrm{n}$ \\
\hline Panama & 1975 & 1.2 & -0.6 & 5.3 & $\mathrm{y}$ & $\mathrm{n}$ & $\mathrm{y}$ \\
\hline Papua New Guinea & 1987 & 0.0 & -4.1 & 4.0 & $\mathrm{y}$ & $\mathrm{n}$ & $\mathrm{y}$ \\
\hline Paraguay & 1974 & 3.9 & 4.3 & 6.2 & $\mathrm{n}$ & $\mathrm{n}$ & $\mathrm{n}$ \\
\hline Peru & 1959 & -6.0 & 10.6 & 5.2 & $\mathrm{n}$ & $\mathrm{n}$ & $\mathrm{n}$ \\
\hline Poland & 1992 & 1.9 & 3.5 & 5.0 & $\mathrm{n}$ & $\mathrm{n}$ & $\mathrm{n}$ \\
\hline Portugal & 1985 & 2.7 & 4.3 & 5.4 & $\mathrm{n}$ & $\mathrm{n}$ & $\mathrm{n}$ \\
\hline Romania & 1979 & 6.5 & -2.1 & 12.4 & $\mathrm{y}$ & $\mathrm{n}$ & $\mathrm{y}$ \\
\hline Rwanda & 1975 & -2.1 & 15.1 & 4.0 & $\mathrm{n}$ & $\mathrm{n}$ & $\mathrm{n}$ \\
\hline Singapore & 1969 & 12.5 & 12.3 & 8.2 & $\mathrm{y}$ & $\mathrm{y}$ & $\mathrm{n}$ \\
\hline Spain & 1959 & -4.5 & 8.2 & 8.0 & $\mathrm{n}$ & $\mathrm{n}$ & $\mathrm{n}$ \\
\hline Spain & 1984 & 0.7 & 1.0 & 3.8 & $\mathrm{n}$ & $\mathrm{n}$ & $\mathrm{n}$ \\
\hline Sri Lanka & 1979 & 0.5 & 1.1 & 4.1 & $\mathrm{n}$ & $\mathrm{n}$ & $\mathrm{n}$ \\
\hline Syria & 1969 & 11.4 & -19.2 & 5.8 & $\mathrm{y}$ & $\mathrm{y}$ & $\mathrm{y}$ \\
\hline Syria & 1974 & 5.2 & 17.1 & 4.8 & $\mathrm{n}$ & $\mathrm{y}$ & $\mathrm{n}$ \\
\hline Syria & 1989 & -10.0 & 6.3 & 4.4 & $\mathrm{n}$ & $\mathrm{n}$ & $\mathrm{n}$ \\
\hline Taiwan & 1961 & 4.0 & 4.6 & 7.1 & $\mathrm{n}$ & $\mathrm{n}$ & $\mathrm{n}$ \\
\hline Thailand & 1957 & 10.9 & -0.6 & 5.3 & $\mathrm{y}$ & $\mathrm{y}$ & $\mathrm{y}$ \\
\hline Thailand & 1986 & 3.0 & 7.2 & 8.1 & $\mathrm{n}$ & $\mathrm{n}$ & $\mathrm{n}$ \\
\hline Trinidad \&Tobago & 1975 & 1.4 & 8.5 & 5.4 & $\mathrm{n}$ & $\mathrm{n}$ & $\mathrm{n}$ \\
\hline Tunisia & 1968 & 9.7 & 4.7 & 6.6 & $\mathrm{y}$ & $\mathrm{y}$ & $\mathrm{n}$ \\
\hline Uganda & 1977 & -0.8 & -6.3 & 4.0 & $\mathrm{y}$ & $\mathrm{n}$ & $\mathrm{y}$ \\
\hline Uganda & 1989 & 1.3 & 5.2 & 3.6 & $\mathrm{n}$ & $\mathrm{n}$ & $\mathrm{n}$ \\
\hline United Kingdom & 1982 & 2.4 & 3.8 & 3.5 & $\mathrm{n}$ & $\mathrm{n}$ & $\mathrm{n}$ \\
\hline United States & 1961 & 0.4 & 4.7 & 3.9 & $\mathrm{n}$ & $\mathrm{n}$ & $\mathrm{n}$ \\
\hline
\end{tabular}


Table 6 (Continued)

\begin{tabular}{llllllll}
\hline Country & $(1)$ & $(2)$ & $(3)$ & $(4)$ & $(5)$ & (6) & (7) \\
& Year & $\begin{array}{l}\text { Growth in } \\
\text { year before } \\
\text { acceleration }\end{array}$ & $\begin{array}{l}\text { Growth in } \\
\text { first year of } \\
\text { acceleration }\end{array}$ & $\begin{array}{l}\text { Average } \\
\text { growth } \\
\text { during } \\
\text { acceleration }\end{array}$ & $\begin{array}{l}\text { Growth } \\
\text { before }> \\
\text { growth at } \\
\text { start? }\end{array}$ & $\begin{array}{l}\text { Growth } \\
\text { before }> \\
\text { growth } \\
\text { during? }\end{array}$ & $\begin{array}{l}\text { Growth } \\
\text { at start } \\
<0 ?\end{array}$ \\
\hline Uruguay & 1974 & 1.8 & 5.0 & 4.0 & $\mathrm{n}$ & $\mathrm{n}$ & $\mathrm{n}$ \\
Uruguay & 1989 & 0.1 & -0.9 & 3.8 & $\mathrm{y}$ & $\mathrm{n}$ & $\mathrm{y}$ \\
Zimbabwe & 1964 & 5.6 & 10.1 & 7.2 & $\mathrm{n}$ & $\mathrm{n}$ & $\mathrm{n}$ \\
\hline
\end{tabular}

Notes: column (1) indicates the start of the acceleration; column (2) shows the rate of growth in the year preceding the acceleration; column (3) contains the growth rate at the start of the acceleration; column (4) presents the average growth rate during the episode; column (5) indicates whether the growth before the start of the acceleration exceeds the growth rate at the start of the episode ( $y=y e s ; n=$ no); column (6) indicates whether the growth before the start of the acceleration exceeds the average growth rate of the episode; and column (7) shows whether there is a negative growth rate at the start of the episode

it seems that episodes falling in the first category are identified too early, while episodes falling in the latter categories are identified too late. ${ }^{16,17}$

There are substantial differences between accelerations based on the filter of Hausmann et al. (2005) and those based on our filter. Only 28 episodes (33\%) are identified at exactly the same date, 31 episodes (37\%) differ one year, while 15 episodes (18\%) are identified with a difference of more than one year. Furthermore, our filter does not pick up 9 episodes, which are identified by the filter of Hausmann et al. (2005) as these episodes do not fulfill the condition that the growth rate at the first year of the acceleration should be larger than the growth rate in the year before the acceleration. ${ }^{18}$ Finally, we identify 10 episodes not found by Hausmann et al. (2005).

\section{References}

Brambor, T., Clark, W. R., \& Golder, M. (2006). Understanding interaction models: Improving empirical analyses. Political Analysis, 14(1), 63-83.

Chamberlain, G. (1980). Analysis of covariance with qualitative data. Review of Economic Studies, 47(1), $225-238$.

Clague, C., Keefer, P., Knack, S., \& Olson, M. (1996). Property and contract rights in autocracies and democracies. Journal of Economic Growth, 1(2), 243-276.

\footnotetext{
${ }^{16}$ The reason why the filter is unable to identify the start of the growth acceleration adequately is the use of the spline regression method. If one break is allowed in the fitted function, its optimal position is also affected by the volatility and other breaks in the series. As a consequence, the criterion of the highest F-statistic of the fitted function gives the best-fitted line through the GDP series, but not necessarily the optimal location of the break.

${ }^{17}$ We checked whether our episodes suffer from the same problem as dealt with in Table 6. In turns out that on two occasions our filter identifies an acceleration which is preceded by a year that has a higher growth rate than the average growth rate during the entire acceleration: Congo (1969) and Pakistan (1965). In the case of Congo, the actual growth acceleration started before the sample period, i.e., 1967. The situation of Pakistan is different as 1965 is the first possible start after the previous acceleration.

${ }^{18}$ These episodes are (starting year in parenthesis): Guinea-Bissau (1988), Haiti (1990), Malawi (1992), Mali (1972), Papua New Guinea (1987), Poland (1992), Syria (1974), Uganda (1977), and Uruguay (1989).
} 
Crain, W. M. (2003). Volatile states. Institutions, policy, and the performance of American state economies. Ann Arbor: University of Michigan Press.

Cuberes, D., \& Jerzmanowski, M. (2008). Democracy, diversification, and growth reversals (Mimeo). Department of Economics, Clemson University.

De Haan, J. (2007). Political institutions and economic growth reconsidered. Public Choice, 131(3), 281292.

De Haan, J., Lundström, S., \& Sturm, J. E. (2006). Market-oriented institutions and policies and economic growth: A critical survey. Journal of Economic Surveys, 20(2), 157-191.

Doucouliagos, C., \& Ulubasoglu, M. (2008). Democracy and economic growth: A meta-analysis. American Journal of Political Science, 52(1), 61-83.

Durlauf, S., Johnson, P., \& Temple, J. (2005). Growth econometrics. In P. Aghion \& S. Durlauf (Eds.), Handbook of economic growth (pp. 555-677). Amsterdam: Elsevier.

Giavazzi, F., \& Tabellini, G. (2005). Economic and political liberalizations. Journal of Monetary Economics, 52(7), 1297-1330.

Gwartney, J., \& Lawson, R. (2008). Economic freedom of the world: Annual report 2008. http://www. freetheworld.com/release.html.

Harding, D., \& Pagan, A. R. (2002). Dissecting the cycle: A methodological investigation. Journal of Monetary Economics, 49(2), 365-381.

Hausman, J. (1978). Specification tests in econometrics. Econometrica, 46(6), 1251-1271.

Hausmann, R., Pritchett, L., \& Rodrik, D. (2005). Growth accelerations. Journal of Economic Growth, 10(4), 303-329.

Heston, A., Summers, R., \& Aten, B. (2002). Penn world table version 6.1. Center for International Comparisons at the University of Pennsylvania (CICUP).

Imam, P., \& Salinas, G. (2008). Explaining episodes of growth accelerations, decelerations, and collapses in Western Africa (IMF Working Paper 08/287).

Jerzmanowski, M. (2006). Acceleration, stagnation and crisis: The role of macro policies in economic growth (Working paper). Clemson University.

Jones, B. F., \& Olken, B. A. (2005). Do leaders matter? National leadership and growth since World War II. Quarterly Journal of Economics, 120(3), 835-864.

Jones, B. F., \& Olken, B. A. (2008). The anatomy of start-stop growth. Review of Economic and Statistics, 90(3), 582-587.

Jong-A-Pin, R. (2009). On the measurement of political instability and its impact on economic growth. European Journal of Political Economy, 25(1), 15-29.

Jong-A-Pin, R., \& De Haan, J. (2008). Growth accelerations and regime changes: A correction. Econ Journal Watch, 5(1), 51-58.

Jong-A-Pin, R., \& Yu, S. (2010). Do coup leaders matter? Leadership change and economic growth in politically unstable countries (KOF Working Papers, no. 247). KOF Swiss Economic Institute, ETH Zürich.

Marshall, M. G., \& Jaggers, K. (2002). Polity IV data set [Computer file; version p4v2002]. College Park, MD: Center for International Development and Conflict Management, University of Maryland.

Olson, M. (1982). The rise and decline of nations: Economic growth, stagflation, and social rigidities. New Haven: Yale University Press.

Pritchett, L. (2000). Understanding patterns of economic growth: Searching for hills among plateaus, mountains, and plains. World Bank Economic Review, 14(2), 221-250.

Przeworski, A., Alvarez, M., Cheibub, J. A., \& Limongi, F. (2000). Democracy and development: Political regimes and economic well-being in the world 1950-1990. New York: Cambridge University Press.

Rodríguez, F., \& Rodrik, D. (2001). Trade policy and economic growth: A skeptic's guide to the cross-national evidence. In B. Bernanke \& K. Rogoff (Eds.), NBER macroeconomics annual 2000 (pp. 261-338). Cambridge: MIT Press.

Sachs, J., \& Warner, A. (1995). Economic reform and the process of global integration. Brookings Papers on Economic Activity, 1, 1-95.

Tavares, J., \& Wacziarg, R. (2001). How democracy affects growth. European Economic Review, 45(8), $1341-1378$.

Timmer, M. P., \& De Vries, G. (2009). Structural change and growth accelerations in Asia and Latin America: A new sectoral data set. Cliometrica, 3(2), 165-190.

Vanhanen, T. (2000). A new dataset for measuring democracy, 1810-1998. Journal of Peace Research, 37(2), 251-265.

Wacziarg, R., \& Welch, K. H. (2008). Trade liberalization and growth: New evidence. World Bank Economic Review, 22(2), 187-231.

Winters, L. A. (2004). Trade liberalisation and economic performance: An overview. The Economic Journal, 114(493), F4-F21. 